\title{
OA04.03. Neural responses to the mechanical characteristics of a spinal manipulation: effect of varying direction of the applied thrust force
}

\author{
J Pickar ${ }^{1 *}$, W Reed ${ }^{1}$, C Long ${ }^{1}$, G Kawchuk ${ }^{2}$ \\ From International Research Congress on Integrative Medicine and Health 2012 \\ Portland, Oregon, USA. 15-18 May 2012
}

\section{Purpose}

A goal of our laboratory is to identify mechanisms of action operative during the body-based practice of spinal manipulation. Spinal manipulation can be identified by a number of mechanical characteristics including but not limited to thrust rate, magnitude, site, and direction. Because neural mechanisms are thought to contribute to its clinical effects, we studied spinal manipulation during a series of experiments to identify mechanical characteristics that affect responses from sensory neurons innervating paraspinal tissues. Presumably specific parameters related to these characteristics relate to successful clinical outcomes. In this study we determined the effect of manipulative thrust direction on neural activity of proprioceptive afferents from lumbar paraspinal muscles.

\section{Methods}

In anesthetized cat preparations $(\mathrm{n}=18)$, a simulated spinal manipulation (100ms thrust duration) was delivered in each of 5 directions [posterior-to-anterior $\left(0^{\circ}\right)$, cranialward $\left(15^{\circ} \& 30^{\circ}\right)$, and medialward $\left.\left(15^{\circ} \& 30^{\circ}\right)\right]$ to the prone, intact lower lumbar spine $\left(\mathrm{L}_{6}-\mathrm{S}_{1}\right)$ using the $\mathrm{L}_{6}$ lamina as the contact site. Importantly, we increased thrust force as we deviated thrust direction from vertical in order to keep the force component that was perpendicularly-oriented to the contact site constant at $21.3 \mathrm{~N}$ ( $55 \%$ of an average cat's body weight of $3.95 \mathrm{~kg}$ ). During the manipulative thrust, electrophysiological recordings from individual muscle spindle afferents innervating the $\mathrm{L}_{6}$ multifidus and longissimus muscles were obtained from $\mathrm{L}_{6}$ dorsal rootlets exposed through an $\mathrm{L}_{5}$ laminectomy.

\section{Results}

Muscle spindle discharge frequency during P-A- $0^{\circ}$ thrust increased 81.6 (89.1, 98.0; 95\% CI), during cranialward$15^{\circ}$ increased 101.4 $(93.1,109.6)$, during cranialward $-30^{\circ}$ increased $82.8(90.3,96.6)$, during medialward $-15^{\circ}$ increased $104.6(93.4,115.8)$, and during medialward $-30^{\circ}$ increased $87.6(69.8,105.5)$ impulses/sec.

\section{Conclusion}

Our results suggest that for the same vertically-oriented force component, thrust direction had little effect on muscle spindle responses. These data provide neurophysiological evidence that only the component of the manipulative thrust normally-oriented to the contact site is transmitted to deeper tissues.

\section{Author details}

'Palmer Center for Chiropractic Research, Davenport, USA. ${ }^{2}$ University of Alberta, Edmonton, Canada.

Published: 12 June 2012

doi:10.1186/1472-6882-12-S1-015

Cite this article as: Pickar et al: OA04.03. Neural responses to the mechanical characteristics of a spinal manipulation: effect of varying direction of the applied thrust force. BMC Complementary and Alternative Medicine 2012 12(Suppl 1):015.

Palmer Center for Chiropractic Research, Davenport, USA

Full list of author information is available at the end of the article

(C) 2012 Pickar et al; licensee BioMed Central Ltd. This is an Open Access article distributed under the terms of the Creative Commons 